\title{
Dystrophy of the Sense of Incomprehension and its Consequences
}

Original article

DOI: $10.31992 / 0869-3617-2021-30-2-50-60$

Oleg A. Donskikb - Dr. Sci. (Philosophy), Head of the Department of Philosophy and Humanities, o.a.donskih@nsuem.ru

Novosibirsk State University of Economics and Management, Novosibirsk, Russia

Address: 56, Kamenskaya str., Novosibirsk, 630099, Russian Federation

Novosibirsk State Technical University, Novosibirsk, Russia

Address: 20, K. Marx prospect, Novosibirsk, 630073, Russian Federation

Abstract. The problem under investigation directly relates to a radically new social situation the possibility to immediately get any information, which has drastically changed the process of education. This situation has superimposed some previous tendencies, particularly the simplification of tasks and diminishing of challenging conditions of education from the very beginning, which leads to diminishing the joy of learning and efforts to overcome difficulties. The trend towards early specialization plays the same role, because in reality it usually only leads to the exclusion of some subjects. Special attention is given to the distinction between information and knowledge. The crucial difference is between "obtaining knowledge" and "being informed". Generally speaking, in the first case, a person has to construct an integrated picture of the fragment of reality with different links and relationships between parts of this picture. In the second case, the bits of information are added to something already known without endeavor to continue any further work to understand the subject on a deeper level. In relation to the process of comprehension, this means that in the first case we move from the surface level to the deeper one, while in the second case we are left on the surface level. Short-term memory is used instead of long-term memory. Also, the changed ratio between oral and written communication is analyzed. Due to the habitual practice of communication using electronic devices, the predominantly oral verbal dialogues are replaced with written ones. Therefore, the connection between actors of communication becomes 1) stretched and more muddled due to the mediation of written text, and 2) much narrower, because it lacks additional hints usual for oral communication. The integral result of such education expresses itself in a certain quality of personality that can be described as "the acquired dystrophy of the sense of incomprehension." It has extremely significant negative consequences related to the formation of a free personality, for social life, and for genuine professional education.

Keywords: sense of incomprehension, immediate access to information, simplification of the process of education, levels of understanding, short-term memory, long-term memory, gadgets

Cite as: Donskikh, O.A. (2021). Dystrophy of the Sense of Incomprehension and its Consequences. Vysshee obrazovanie $v$ Rossii = Higher Education in Russia. Vol. 30, no. 2, pp. 50-60, doi: 10.31992/0869-3617-2021-30-2-50-60 


\section{Дистрофия чувства непонимания и её последствия}

Научная статья

DOI: 10.31992/0869-3617-2021-30-2-50-60

Аонских Олег Альбертович - А-р филос. наук, зав. кафедрой философии и гуманитарных наук, o.a.donskih@nsuem.ru

Новосибирский государственный университет экономики и управления, Новосибирск, Россия Адрес: 630099, Новосибирск, ул. Каменская, 56

Новосибирский государственный технический университет, Новосибирск, Россия Адрес: 630073, Новосибирск, просп. К. Маркса, 20

Аннотация. Обсуждаемая проблема непосредственно связана с радикально новой сочиальной ситуачией, обусловленной Интернетом, - Возможностью немедленно получить любую информачию, которая коренньм образом изменила прочесс образования. Эта ситуачия наложилась на некоторые предшествуюшие тендениии, в частности на упрощение задач и уменьшение с самого начала сложностей в прочессе обучения, что ведёт к уменьшению радости узнавания нового и минимизачии усилий по преодолению трудностей. Формируется привычка к отсутствию серьёзных вызовов уже на ранних стадиях учёбь. Тендениия к ранней спещиализачии играет ту же роль, поскольку она обьчно приводит лишь к исключению некоторьх предметов, которье вызььвют у учашегося затруднения, и эта ситуачия только закрепляется со временем. Эти тендениии продолжаются и закрепляются на уровне высшего образования. Особое внимание в статье уделяется различюю между информачией и знанием. Приниипиальную разничу можно обозначить благодаря сравнению двух высказываний: «приобретать знания» и «получать информачию». В первом случае учашийсл должен построить ијелостную картину определённого фрагмента действительности, осознать её структуру с разлиньми связями и отношениями между частями этой картинь. Во втором случае бить информачии добавляются к чему-то уже известному без каких-то попьток продолжить дальнейшую работу по пониманию предмета на более глубоком уровне. По отношению к прочессу постижения предмета это означает, что в первом случае мь переходим с поверхностного уровня на более глубокий, и это формирует многомерность, а во втором- остаёмся наплоском поверхностном уровне. Кроме того, вместо тренировки долговременной памяти постоянно задействуется кратковременная. В статье анализируется радикальное изменение соотношения между устным и письменньм общением. Из-за привьчной практики общения с использованием электронных устройств преимушественно устные диалоги заменяются письменными. Поэтому связь между субъектами коммуникачии становится 1) растянутой и более запутанной вследствие опосредования диалогов письменньми текстами, и 2) значительно более плоской и однозначной, поскольку в ней отсутствуют дополнительные налёки и сопутстьующие знаки, обычнье для устного общения. Интегральньй результат такого обучения вьражается в определённом качестве личности, которое можно охарактеризовать как «приобретённая дистрофия чувства непонимания». Это качество создаёт значительньй негативный эфрект, препятствуя формированию свободной личности, а это, в свою очередь, имеет негативные последствия как для полноценной общественной жизни, так и для настоящего профессионального образования.

Ключевые слова: чувство непонимания, непосредственньй доступ к информачии, упрощение прочесса обучения, уровни понимания, кратковременная память, долговременная память, гаджеть 
Аля иитирования: Donskikh O.A. Dystrophy of Sense of Incomprehension and its Consequences // Высшее образование в России. 2021. Т. 30. № 2. С. 50-60. DOI: 10.31992/0869-36172021-30-2-50-60

I consider the consciousness of incomprehension to be the highest in man.

\section{Friedrich Heinrich Jacobi}

\section{Introduction and the statement of the problem}

The problem discussed in this paper is regarded to be a crucial problem which is faced by university lecturers as well as by school teachers: teaching in a world where any information is readily available, which, in particular, immediately creates a second problem - the problem of the dystrophy of the sense of misunderstanding. This second problem is essentially determined by the first one and in its turn acts on the principle of positive feedback. It reinforces the negative effect of this situation and, accordingly, forms a negative environment for effective learning.

The state of affairs at all levels of education is now the following: 1) pupils at school and students at university can almost always immediately obtain any information which they need (or think that they can obtain what they need), and 2) personal communication including communication between pupil and teacher or between student and professor, is mediated by gadgets, which reorganize the very structure of the correspondence process.

This leads to a situation where students:

a) cannot form a critical reflective attitude to the information which they have received;

b) are losing the idea of its value in relation to the knowledge of the subject;

b) in principle in the course of education do not obtain the slightest idea of the ways of gaining knowledge;

d) do not form an integrated picture of any object or phenomenon, but a mosaic representation, which does not allow to ask corresponding questions and, accordingly, to respond to them.

In addition, all these problems are compounded, in particular, by the tendency to simplify the process of getting education. This tendency is quite understandable, because almost all members of modern society are currently involved in some forms of training. In other words, it is defined and demanded by mass education and the necessity to often change qualifications as well as to develop new forms of job activity in the framework of a professional career.

Mass education, if compared with education of some chosen groups of society, requires a corresponding change of programs and ways of teaching for school teachers as well as for professors of universities, and accordingly for those who are learning. The basic principle of this change is to improve its maintainability. Using an analogy, we can compare this situation with the transition from guild handicraft to manufacture and eventually to the rolling ramp or conveyor system. In the first case, a craftsman had been trained for years in order to be able to do some particular thing from beginning to end. Manufacture allows to split the process into elementary operations, and it is enough to learn some simple operations in order to have the same product at the end of the production chain. It is no longer necessary to teach the craftsman all the steps required for the production of the product. The emphasis moves from learning bow to do a thing to the organization of joint activities. The management of the process starts to play a more and more considerable role. The master is replaced by the manager. If this analogy is continued, with the spread of such organization of labour, many people appear who can process some operations quite well, however if the end product is really complicated, they are unable to make it fully from scratch, be it a wristwatch or a musical instrument.

This trend of "manufacturing" education is manifested in a number of ways, not always related to each other for an outside observer. 


\section{The crucial difference between knowledge and information}

Let us start with the fact that in elementary mass school the conditions are arranged in such a way that would almost totally exclude possible stressful situations. This applies to assessments when, for example, any negative judgments are minimized or even removed from classroom practice completely. In addition, the competition for the best performance is minimized or basically absent. With this, the endeavor to compete and to overcome difficulties is also minimized. It is sacrificed to the corresponding acceptance of the goals of primary education, that it should be turned exclusively into a game. This is understandable, because game at this age is a natural process of the acquisition of the outer environment. Yet the ability to acquire a custom for training to overcome difficulties is almost completely sacrificed. There is also the simplification of the content of the programs due to the exclusion of such subjects as, for instance, handwriting, which eliminates the purchase of such important abilities as fine motor skills, etc.

Special importance is given to the early specialization, based on the idea that some particular abilities are to be developed for the advantage of a unique personality, therefore the individual trajectory of education should be organized. The specific inborn abilities are to be considered and trained on behalf of the development of others. Particular areas of knowledge and training become priority from the age when these abilities cannot be properly defined. This specialization by definition 1) does not lead to the formation of a harmonic personality, and 2) excludes the more difficult subjects from the content of the education for particular persons. Generally speaking, this looks the same as if, upon discovering that a child likes ice cream more than porridge, a parent starts to significantly increase the amount of ice cream in his diet, accordingly reducing portions of porridge. As a result, children find themselves in a hothouse atmosphere, become accustomed to it and become almost unable to respond to serious challenges of various kinds, which are later presented in the life of an adult. This system of education is changing the nature of what is called curiosity, because children are taking what comes easier as "interesting." They do not need to overcome laziness of mind in order to master certain branches of mathematics or natural sciences, or to delve into topics raised and developed by great writers. This situation in fact denies the very joy of learning. Referring to the recent practice of school education, it is enough to cite the example of making simple numeral calculations in one's mind. The use of calculator at the early stages of learning arithmetic leads to the fact that in the end, pupils are unable to do the most primitive calculations in their mind, but - and this is, probably, more significant - in principle do not recognize, do not perceive the very orders of the magnitude of numbers. For them, the multiplication of hundreds can be easily represented by the numbers of the third or fourth order, etc. The fact is that if they are faced with such absurdities, they take them as normal and, consequently, do not react to them correspondingly. This situation already directly relates to our topic - pupils do not have the sense of discrepancy between their answer and the possible solution of the task which involves the result of multiplication or division.

The availability of information supports the same trend of the simplification of education followed by real job tasks. It is so easy to obtain any information just by pressing some buttons, that, consequently, preparation of any reports, reviews and papers, learning of particular topics transforms into the acquisition of various pieces of randomly gotten information. Basically, this means that instead of writing, the process turns into adding chosen pieces which relate to the topic, and gluing them together using intermediate words. The main problem with this is that understanding of the topic is surface level at best.

In order to characterize this situation, it is quite useful to discriminate between information and knowledge. "We ordinarily use data to provide us with information about something of 
which we are uncertain ... If you had probability near 1 for an event, you would feel you had a fair amount of information about the event, feeling confident in its truth; and similarly with probability near 0 , leading to some assurance that it was false. On the contrary, with probability of $S$ you have little information, feeling the event is as likely to be true as to be false. Considerations such as these suggest that your information about an event depends on your probability $p$ for the event, decreasing with $\mathrm{p}$ as $\mathrm{p}$ increases from 0 , reaching a minimum at $p=$ $\mathrm{S}$ and then increasing to its original value at $\mathrm{p}$ $=1$ " [1, p. 98-99]. Thus, the crucial difference is in obtaining knowledge and being informed. Generally speaking, a person in the first case has to construct an integrated picture of the fragment of reality with different links and relationships between parts of this picture. In the second case, the bits of information are added to something already known without any endeavor to continue any further work with this. Therefore, the result of learning becomes dramatically different: in the first case, it is a multi-layered and multidimensional image of some particular subject open to further questioning. "The mind constructs meaning through a flexible range of comprehending strategies that work together (perhaps unconsciously) to maintain the highest possible order of understanding" [2, p. 11]. In the second case, as a result, we have a set of flat pictures without any meaningful links between them. In this case, a complex meaning does not appear. Quite significant difference between knowledge and information is indicated by V. Zinchenko - "Knowledge is always someone's, someone's own, it cannot be bought, stolen from the knowledgeable (except together with the head), and information is no man's territory, it is impersonal, it can be exchanged or stolen, which often happens. The language is sensitive to this difference" [3, p. 84]. This means that knowledge is becoming a part of personality while information is not. Knowledge as the indicative basis of activity is presented in the works of A. Verbitsky [4]. The greatest danger of this situation is that student while just acquir- ing some information acquires illusion that what is remembered is what is known [5, p. 82]. This means in this case that the process of education is directed towards false objectives.

\section{Levels of comprehension and new technologies}

Let us turn to the simplest scheme of levels of comprehension. We have to discriminate between surface and deep levels: "The surface level of comprehension is a literal level of understanding represented by the ability to recall factual information from the text. This retrieval process involves short-term memory; thus, this level of understanding directly relates to the recency of the reading. The desire to think beyond the surface level requires motivation" ... while the deep level is "a conceptual level of understanding that results from the reader's ability to think beyond the text, thus integrating the author's intentions with the reader's point of view. At this level, the author's message serves as a pivotal point in regulating the reader's deeper thinking. The text becomes reconstructed or tailored in the reader's mind to accommodate the reader's background experience and personal goals. Deep comprehension is the result of the mind's analyzing and synthesizing multiple sources of information, thus lifting a reader's comprehension to new levels of meaning" [2, p. 14]. Obviously, this process is far from just getting information. One of key words which characterize the path to deep understanding is motivation, but the access to immediate resources of information prevents the aspiration for deeper knowledge, i.e. to form a more and more integrated picture of the subject in question. The motivation is directed towards formal performance of the task rather than towards substantive understanding of the subject. Only in this instance, information is needed to combine the different aspects of the subjects into an integrated image and this makes it multifaceted and open to continuation. This process obviously requires involvement of long-term memory rather than simple reaction to surface incentives.

It is clear that in order to avoid misinterpretation, a speaker as well as a listener should 
refer to the same linguistic knowledge, and the same perspective. Genuine understanding is not possible otherwise. This follows from the simple fact of the asymmetry between language production and comprehension. "...The optimal form for a speaker may not always be understandable for a listener. Likewise, the optimal meaning for a listener may sometimes be different from the meaning that was intended by the speaker. In such cases, the perspectives of speaker and listener are in conflict. To achieve successful communication, speakers and listeners must coordinate their choices by taking into account the perspective of their conversational partner" [6, p. 190]. Moreover, “... speakers and listeners take opposite - and sometimes even competing - perspectives in their use of language. Speakers proceed from a given meaning and select the optimal form for expressing that meaning. Listeners, on the other hand, proceed from a heard form and select the optimal meaning for that form. This means that special attention should be paid to the ratio between oral and written communication. Oral communication is always supported by a close environment, and also by eye-contact. The situation is dramatically changed by the ongoing turn towards gadgets which have determined the necessity to use written communication instead of oral. Normal oral communication involves different indications which facilitate the comprehension of speech. The exchange of messages through smartphones lacks these possibilities. In order to compensate it, the messages are becoming much shorter and simpler. And this is becoming the standard way of communication. "... If the threshold for understanding is quite low, a child may fail to recognise that their understanding has broken down in some way or be inclined to allow misunderstandings to be left without further clarification" [7, p. 73]. Therefore, customary use of written text in itself is changing the attitude to communication in general. The connection between actors of communication becomes 1) stretched and more muddled, due to the mediation of written text, and 2) much more narrow, because it lacks additional hints usual for oral communication, including intonation, facial expressions, surroundings, and ambience. In essence, it becomes more primitive.

We have to take a closer look at this situation, which is even more complicated, from another point of view. With the arrival of new technologies one more dimension of human life should be taken into account - the communication is not only mediated, but organized and controlled by gadgets. Joss Hands, considering the definition of gadget from Cambridge online dictionary, which is a 'small device or machine with a particular purpose', asks a truly disturbing question: "purpose in the purview of the person using the gadget, or is it the gadget that directs the purpose of the user?" [8, p. 5]. It is obvious, just observing the behavior of the users of gadgets, that it is substantially determined by the devices. Analyzing this situation, Hands states that "...the invariable element is the always-intentional stance humans take towards the world, one that interprets it and builds a sense, both individual and collective, of what that world is and our place in it. It is the content of the self-consciousness that varies according to the specific technologies involved" $[8$, p. 30]. In relation to modern gadgets, including smartphones, personal computers etc., this means that we have to accept not only "their presence and centrality in modern life, but also understanding their double-sided potentiality, represented by the dangers they present in the way of dominating and alienating us, of limiting our connections with nature and with each other..." [8, p. 32]. Taking the example of Twitter, Hands concludes that "Twitter's combination of short-form micro-blogging - offering succinct but fully formed propositions, observations, imperatives and so forth - with scale-free connectivity at great speed, and with the capacity to cluster and disseminate bounded frames of discourse, produces a qualitative shift of capacity. This can be equated with the idea of a phase shift. A phase shift occurs when a particular substance or entity reaches a certain stage at which there is a shift to another kind of state, for example when water turns to ice, or when a 
crowd turns from a collection of individuals into a coordinated group with a singular purpose" [8, pp. 112-113]. The way of behavior is determined not by reasoning based upon understanding of the situation but by the use of a gadget.

In addition, we have to keep in mind the tendency to ask for opinions, when a particular topic is not well known yet. This prompts an illusion of the equality of opinions in a situation when the one who really knows some subject in its links and different aspects while another expresses his/her opinion on the level of words, rather than content. Yet further diving into a subject, further clarification is not required. Again, we have an asymmetrical state of affairs, when the actual understanding quite often is not gained. It should be borne in mind that memory in a society where oral communication plays a decisive role, on average, was much more developed than that of our contemporaries, when it is always possible to find the right link, the desired text in a book, or at any time turn to the help of a smartphone. It was necessary to keep long chains of reasoning in mind. This means the constant involvement of long-term memory, because it is there that the multidimensional picture of comprehended reality is formed. Consequently, the possibility of receiving some information at any moment develops short-term memory at best, but this is not enough to come to the necessity of questioning.

Let us now turn to the concept of understanding, taking the comprehension of literary text as an example. This process is quite complicated if we mean the effort to understand classical composition beyond its literal level. Arthur Graesser indicates that one "... point that has consistently been emphasized is that statements in text are interrelated by conceptualizations that contain a large number of inferences. For example, a typical statement in a narrative passage generates 15 distinct inferences, on the average" [9, pp. 262-263]. These inferences refer to the older knowledge, including personal experience of a reader, his knowledge of other literary compositions, facts from history of peoples, etc. Also, the process of understanding is influ- enced by the motivation and aim of the reader, which results in a situation when "some new nodes (that are generated by an incoming target statement) are more or less equivalent to old nodes that are part of the conceptual structure that was available before the target statement was received. An equivalent pair of nodes (old and new) would obviously be bound together. This binding process provides the foundation for synchronizing new and old information." [9, p. 271]. The process of comprehension is also based upon formed mentality, including a crucial cultural component. "Norms of personal relationships and customs ... change, even within a single culture, and without an understanding of the conventions in force at the time or place in which a work was written, misreadings or total incomprehension may result. Literary forms and aesthetic ideas also develop in response to the changing conditions of society, and a good reader must acquire enough knowledge of the social, political and economic background as well as of the history of ideas and aesthetic values to place an individual piece of literature, an author's entire work or that of a school of writers in its proper context" [10, p. 17]. This means that understanding of the verbatim meaning of any composition is needed as just the first step towards deeper meanings.

If we ask the question what makes the reader move towards deeper and deeper understanding, the answer is quite obvious - it is curiosity, the ability to ask questions and seek answers. A person has to develop the ability to be surprised. According to Aristotle, surprise is necessary to fix the situation of misunderstanding or ignorance. This situation, in turn, generates interest, raises questions, and those require systematic research. Learning to misunderstand turns out to be key with this approach. "Realizing the world in the process of self-construction, a person discovers gaps that violate the integrity of the picture. The gaping of these lacunae surprises, alarms and requires awareness and response. Then attention rushes to fill them. This process is radically different from the process of constructing random mosaic planes, where the 
connection of the incompatible does not force student to ask questions and, accordingly, does not provoke research" [11, p. 115]. Yet only research incited by striving for wholeness leads towards genuine knowledge. The wholeness is present a) in the obligatory establishment of generic relations when considering any object of research and in establishing a system of the most general categories; b) in the methodological support of knowledge. This approach refers to the comprehension, design and presentation of knowledge. Certainly, information is necessary in order to fill the exposed lacunae. Yet if there is no corresponding structure which is formed in the process of constructing the picture of some phenomenon, i.e. aspiration to receive the knowledge of it, the information is just added on the surface level, not helping to move to anything deeper.

The situation characterized above certainly does not guide students to deepen their knowledge, rather it creates and maintains the conditions which keep them on the surface level.

Thus, we have the following: 1) simplification of the process of education both in content and in a way of getting knowledge; 2) transfer of information rather than transfer of knowledge, and consequently training of short-term memory instead of long-term memory; 3) transition from predominantly oral communication to communication mediated by written texts; 4) communication and even companionship is now mostly ruled by gadgets.

The system of education, which is quite conservative by definition, is not really ready to challenge these changes.

\section{Examples and discussion}

Some conclusions can be made from the analysis of more than 2600 answers during the Unified State Examination in social sciences for the secondary school course. The weakest answers are almost always given for the task of composing a plan for a particular topic. The fact is that the plan cannot be made from pieces, because it is necessary to present the subject as a whole using imagination and then element-by- element revealing its content in different aspects and different generalization levels. However, this is fundamentally contrary to the established practice described earlier. In the best case, the response is done in accordance with the specific template, a standard method of presenting any topic regardless of its content. Only about $8-10 \%$ of answers meet the requirements. Let us take the example of a typical answer for the topic "Family and its role in modern society":

1. Family.

1.1. Concept.

2. Society.

2.1. Concept.

2.2. Modern society.

2.3. Condition of modern society.

3 . Role of society.

3.1. Its significance.

4. Role of family in society.

5. Family foundations.

6 . The values of the family and society.

7. The relationship of the family and its role in modern society."

It is easy to observe the simplistic and shallow logic of this approach to the subject. There is no effort to present the concept of family in different aspects taking into account the complicated structure of modern society, the ever changing ways of realization of professional and other duties, which often determine the need to move from one place to another, greatly influencing relationships, new technologies, determining the alteration of roles within family, etc. Instead, we find just play with words, which does not lead to any consistent picture of the given subject. The examples can be easily multiplied.

The most creative task of this exam is a short essay, which is designed to demonstrate the ability to reason referring to the chosen statement. We have a picture which also proves vividly the mentioned features of the described process of education. Only between 5 and $10 \%$ of essays demonstrate an understanding of the subject and an effort to present the corresponding integral picture with fair reasoning and fresh examples. The main feature of the essays is that on average they present a set of quite random as- 
sociations and often almost absolutely unrelated parts, when the text is certainly not thought out structurally but just combined from some pieces lined up one by one. No proper introduction, no conclusion relating to the presented content. Here the cliché "clip thinking" is really consistent with the product obtained. The fact is that, firstly, students do not refer to particular sections of the course for which the tasks are given (in the form of a particular statement) in order to present the possibility to choose the bestknown topic. Secondly, they mostly do not even try to grasp the meaning of the statement, and only respond to familiar words thinking that this will be the easiest. The previous training has taught them to use some standard formulas and count the ways of giving examples. The deficit of general knowledge as well as the impossibility to imagine the subject in its wholeness manifests itself, for instance, in the familiarity in respect to authority of great people. The demanded requirement to express the own opinion of a student, which normally should begin with the phrase "I agree" or "I disagree", leads to the situation when an essay starts with the phrases like "I disagree with Voltaire (respectively Plato, Rousseau, Adam Smith, Solon, etc.) because he did not understand the role of laws in society" or "I agree with Aristotle that research starts from genuine surprise" ... The first thing that caught the student's eye and is to some extent understandable, becomes the main topic of the essay. Standard requirements lead to standard answers. However, instead of even understanding the humor of the situation, the student confidently pats the back of a great personality. The essays demonstrate a striking lack of effort to understand the matter, and just effort to comply with the requirements. There are no signs of determination to go from surface level thinking to anything deeper.

These noted trends continue to work in the higher education system and are only getting stronger, due to the diminishing of the humanitarian courses, which are directed towards formation of personality on behalf specific courses related to the chosen profession.
The lack of a meaningful relationship to the texts is demonstrated by another quite striking fact: the vast majority of undergraduate students cannot do such basic things as just to retell what they have just listened to at a lecture. Therefore, it is useless to talk about the ability to write proper notes during lectures. This situation forces most lecturers to provide their lectures in the primitive form of dictation of certain texts instead of normal oral presentation. However, this way of providing lectures leads to a dead end: instead of developing critical thinking skills, only short-term memory is developed. As a result, at the seminars the students retell misunderstood or poorly understood texts by heart with amazing accuracy, not being able to answer the simplest questions related to what they have just presented. The short-term memory is well trained because it is quite a difficult text to remember, which is not understood at all, however this does not involve long-term memory and consequently does not increase any knowledge.

It is a known fact that Plato was afraid of the spread of books, believing that they would negatively affect the human ability of memorizing and thinking over different texts. He thought that books would weaken the possibility of discussion using just memory and not referring to outer sources. Moreover, the personality of a mentor, his intonations, possibility to ask questions etc., drastically increase the level of comprehension. And so, the written text as such, read by anyone, desecrate, profane the content. The recent situation is much more dangerous in this respect, because any phrases containing the desired word, no matter how irrelevant, will catch the eye and be interpreted as meaningful in any given context. Pure associative thinking is replacing thinking based on concepts and reasoning. Any idea turns out to be a simple association, determined by the reaction of simple recognition. Of course, it allows students to learn certain sequences of words, but it does not require from them more or less deep understanding. It is enough for them just to vaguely guess the meaning. The very meaning of 
the concept of "education" has been changed. In Russian the word "education" (obrazovanie) is a synonym of "creation" and keeps the meaning of the creation, formation of the personality, and namely this meaning is lost.

The integral result of such education expresses itself in a certain quality of personality that can be described as the acquired dystrophy of the sense of incomprehension. Students almost totally lack the sense of incomprehension, which is not just the ignorance in relation to some sphere of knowledge, but the sense of misbalance between some well-known and intuitively assumed content and the newly perceived knowledge. In order to have this sense, knowledge should be organized systematically, not casually. Only in this case, the forming picture of some fragment of reality may cause the intuitive sense of a missed element. The same relates to the sense of wonder, the genuine surprise in the sense of Aristotle. The gap should be formed between something perceived and the position of I who perceives this. Namely, the skill of the formation of such a gap allows to have an integral, holistic picture of some chosen fragment of reality. However, with the students trained to be just associative, neither the formation of concepts nor intuitive insight into the meaning of the subject is present. This is manifested, in particular, in the verbiage which can be found in the above-mentioned essays: instead of discussing the topic, one can find just badly connected words. This flow of words replaces genuine answers. The reflection and freedom of personality are essentially linked with each other. No real knowledge can be acquired in these circumstances, just some casual information.

\section{Conclusion}

The impossibility of forming an independent position in life follows from this situation due to the fact that it principally requires the possibility of reflection - in particular self-reflection. Such reflection requires virtual distance between an observer and the observed, between a picture of future outer possibilities and selfestimated inner possibilities. This means in its turn that the resultant personality is the perfect manifestation of the Kierkegaard's "aesthetic" type of human being, just reacting to the immediate stimuli from the outside world. In this case, the aesthetic life, "the life of inclination, what comes naturally, the life of desire and aversion, of satisfaction and despair" does not have in mind any representation of the possibility of moving to the ethical - "the life of commitment, task, of existential striving to actualize the vision of the good" [12, p. X].

Basically, this means that due to this kind of education, conformism is the most conspicuous feature of students completing the corresponding course. Let us try to imagine the ideal type (in the sense of Max Weber) which, instead of acquiring values consciously formed on the basis of free choice, is formed on a passive reactionary basis and can change without thought. This is essentially the formation of the absolute conformist, who plastically, without any effort to rebuild beliefs (which are absent by definition), adapts to fit any mold. The persuasions are also absent as such because they are replaced by new and new incentives playing their role. This is the completely manipulated creature thinking of itself as really independent and due to this perfectly appropriate for the practice of democracy. (It is clear that a certain amount of conformity is necessary for survival in any society, but it is one case when this conformity is carried out in conditions when it is counterpoised to the system of basic social values, and quite different case when conformism becomes a value in itself. In this case, not only fundamental social values are ruined, but personal values are ruined as well, and this inevitably leads to the disintegration of the personality as such. The question arises, whether personality is a fundamental value? If so (and this is proclaimed by the ideology of the pluralistic society that defends pluralism in the name of a free personality), then due to the system of education, it is sacrificed to the rapidly changing pluralistic public consciousness. This means that pluralistic consciousness which is configured on the guidelines of permanent change, is a much more fundamental 
value than a free personality. We find ourselves before the paradox presented by Dostoyevsky in his novel "The Possessed": the society which proclaims the ideal of free personality is becoming the organization which is suppressing this personality. On the basis of absolute freedom, it arrives at absolute despotism.

The second paradox closely related to the first one is that freedom of personal choice can be guaranteed only by the society, and, accordingly, has to be admitted by this society as a fundamental value. However, a society consisting of conformists is unable to guarantee anything in principle.

Thus, the dystrophy of the sense of incomprehension has extremely significant consequences related to the formation of a free personality, for social life, and with this there are two outcomes for professional education.

First, the outlined specifics of the recent system of education do not allow us to consciously choose what is the most desirable for the development of personality. The person can be oriented towards some profession just by such factors as income and simplicity which facilitate the choice (essentially to avoid a real choice).

Second, as a person cannot define and formulate the problems which are required by a particular situation, the working place is organized in the most technological way being as non-demanding as possible, yet the whole process is organized from outside by managers who themselves are responsible for the diminishing area of competence.

\section{References}

1. Lindley, D.V. (2006). Understanding Uncertain$t y$. New Jersey: Wiley Interscience, $250 \mathrm{p}$.

2. Dorn, L.J., Soffos, C. (2005). Teaching for Deep Comprehension. Portland, Maine: Stenhouse Publishers. $182 \mathrm{p}$.
3. Zinchenko, V. (2003). [Activity. Knowledge. Spirituality]. Vysshee obrazovanie $v$ Rossii $=$ Higher Education in Russia. No. 5, pp. 81-91. (In Russ.).

4. Verbitsky, A. (2016). [The Theory of Contextual Education as a Conceptual Basis for the Implementation of the Competence Approach]. In: Kollektsiya Gumanitarnykh Issledovaniy [Collection of Humanitarian Studies]. No. 2, pp. 6-12. Available at: http://j-chr.com/upload/ выпуск\%202/PDF/Вербицкий.pdf (accessed 10.01.2021) (In Russ., abstract in Eng.).

5. Zinchenko, V.(2005). [Distant, Content... and Education]. Vysshee obrazovanie $v$ Rossii $=$ Higher Education in Russia. No. 7, pp. 76-87. (In Russ.).

6. Hendriks, P. (2014). Asymmetries between Language Production and Comprehension. Springer, $234 \mathrm{p}$.

7. Clarke, P.J., Truelove, E., Hulme, Ch., Snowling, M.J. (2014). Developing Reading Comprehension. Wiley Blackwell, $193 \mathrm{p}$.

8. Hands, J. (2019). Gadget Consciousness. Collective Thought, Will and Action in the Age of Social Media. Pluto Press, $191 \mathrm{p}$.

9. Graesser, A.C. (1981). Prose Comprehension beyond the Word. Springer-Verlag, $310 \mathrm{p}$.

10. Taylor, R. (1981). Understanding the Elements of Literature: Its Forms, Techniques and Cultural Conventions. The MacMillan Press, $234 \mathrm{p}$.

11. Donskikh, O.A. (2018). Why Did Students Stop Asking Questions? Vestnik Tomskogo Gosudarstvennogo Universiteta. Filosofiya. Sotsiologiya. Politologiya = Tomsk State University Journal of Philosophy, Sociology and Political Science. No.42,pp.110-117,doi:10.17223/1998863X/42/11 (In Russ., abstract in Eng.).

12. Hong H.V., Hong E.H. (Eds.). (1980). The Essential Kierkegaard. Princeton University Press, $524 \mathrm{p}$.

The paper was submitted 05.01.21

Received after reworking 07.01.21

Accepted for publication 15.01.20 